\title{
Ekbom Syndrome associated with Lewy Body Dementia A case report
}

\author{
Felippe José Pontes de Mendonça ${ }^{1}{ }^{\mathbb{D}}$, Ivan Abdalla Teixeira' ${ }^{1}$, Valeska Marinho' ${ }^{\circledR}$
}

\begin{abstract}
Ekbom Syndrome, also known as parasitosis delusion or psychogenic parasitosis, is a rare condition in which patients present with a fixed belief of being infested by parasites, vermin or small insects, along with tactile hallucinations (such as pruritus or sensations of the parasites crawling over or under the skin). The syndrome may occur idiopathically or be associated with other medical conditions and drug use. This case report describes the occurrence of Ekbom syndrome in a patient diagnosed with Lewy Body Dementia (LBD), a neurodegenerative disease that commonly presents with sensory perception and thought disorders and other neuropsychiatric symptoms. Although visual hallucination is considered a core diagnostic criterion, other modalities of psychiatric symptoms can also occur posing a further challenge for correct diagnosis. Proper recognition allows early diagnosis and adequate treatment, preventing hazardous antipsychotic use in these patients.
\end{abstract}

Key words: Ekbom syndrome, parasitosis delusion, psychogenic parasitosis, acarophobia, delusional disorders, selfharm, dementias, Lewy Body Dementia.

\section{SÍNDROME DE EKBOM ASSOCIADA À DEMÊNCIA COM CORPOS DE LEWY: UM RELATO DE CASO}

RESUMO. A síndrome de Ekbom, também conhecida como delírio parasitário ou parasitose psicogênica, é uma condição rara na qual os pacientes apresentam crença fixa de estarem infestados por parasitas, vermes ou insetos, acompanhada de alucinações táteis (como prurido ou sensação dos parasitas andando sobre ou sob a pele). A síndrome pode ocorrer de forma idiopática ou associada a outras condições médicas ou uso de drogas. Este relato de caso descreve a ocorrência da síndrome de Ekbom em um paciente diagnosticado com Demência com corpos de Lewy (DCL), uma doença degenerativa que comumente se apresenta com desordens de sensopercepção e pensamento, e outros sintomas neuropsiquiátricos. A alucinação visual é considerada um dos critérios diagnósticos nucleares, entretanto outras modalidades de sintomas psiquiátricos podem ocorrer criando desafios adicionais ao diagnóstico correto. 0 reconhecimento apropriado permite o diagnóstico precoce e tratamento adequado, prevenindo o uso arriscado de antipsicóticos nesses pacientes.

Palavras-chave: síndrome de Ekbom, delírio parasitário, parasitose psicogênica, acarofobia, transtornos delirantes, automutilação, demências, demência com corpos de Lewy.

T kbom syndrome manifests as a delusion Lof infestation of the body by parasites or insects, ${ }^{1}$ where corresponding tactile hallucinations may occur together with the delusional disorder. ${ }^{2}$ A variety of medical conditions may be associated with this syndrome: hypothyroidism, neurodegenerative diseases, anemia, diabetes, peripheral neuropathies, vitamin deficiencies, or drug abuse. ${ }^{3}$ Although there is currently no consensus on

This study was conducted at the Center for Alzheimer's disease and Related Disorders at the Institute of Psychiatry of the Universidade Federal do Rio de Janeiro, RJ, Brazil.

${ }^{1}$ Center for Alzheimer's Disease and Related Disorders, Institute of Psychiatry - Universidade Federal do Rio de Janeiro, RJ, Brazil

Felipe Mendonça. Avenida Venceslau Brás, 71 - 21941-901 Rio de Janeiro RJ - Brazil. E-mail: felippemend@gmail.com

Disclosure: The authors report no conflicts of interest.

Received September 18, 2019. Accepted in final form January 16, 2020.

\section{(cc) BY}


the underlying pathophysiology, lesions involving the temporal lobes, subcortical circuits ${ }^{4}$ and limbic areas ${ }^{5}$ are frequently associated.

The syndrome is most common in women ${ }^{8}$ in the fifth decade of life, with an estimated prevalence of 83.21 million people. ${ }^{9}$ Typically, the symptoms lead to self-mutilation in attempts to remove the parasites, causing excoriations and scarring. ${ }^{9}$ The most affected areas are the scalp, face, mouth, eyes, arms, breasts and genital regions. ${ }^{9}$ Risk factors include isolation, poor social support and low educational status. ${ }^{10}$

Lewy Body Dementia (LBD) is the second-mostfrequent cause of degenerative dementia. ${ }^{11}$ LBD core features are fluctuating cognition, Rapid Eye Movement (REM) behavior disorder, visual hallucinations and parkinsonism. Among the neuropsychiatric symptoms, great emphasis is placed on sensory perceptual disorders, especially visual hallucinations. ${ }^{12,13}$ However, psychiatric manifestations in LBD can be complex and highly heterogenous, ${ }^{14}$ and other symptoms have also been described, such as psychotic depression, ${ }^{14,15}$ catatonia ${ }^{16}$ and delusional disorders (e.g. Capgras syndrome) ${ }^{17}$

Ekbom syndrome is a rare presentation in LBD and was previously described in two case reports of the disease managed with atypical antipsychotics. ${ }^{18}$ However, severe neuroleptic sensitivity may affect up to $50 \%$ of LBD patients and is characterized by worsening cognition, sedation, acute onset parkinsonism and symptoms resembling neuroleptic malignant syndrome..$^{19}$ Owing to these risks, tailored management is advisable to reduce morbidity and mortality due to excessive neuroleptic use. ${ }^{20}$ In this scenario, acetylcholinesterase inhibitors (AChEIs) seem a reasonable choice to treat psychotic symptoms in LBD, but robust evidence for their efficacy in treating these symptoms is still lacking. Considering these issues, we report an LBD case, first presenting as Ekbom syndrome, successfully managed with AchEI, preventing potentially harmful antipsychotic use.

\section{CASE REPORT}

We describe a 72-year-old male retired taxi driver, presenting with complaints of "bugs in his head. Previous medical history included hypertension, dyslipidemia, hypothyroidism and benign prostatic hyperplasia, with no personal or family history of neuropsychiatric disorders.

At 70 years old, he started having trouble finding his passengers addresses, handling money and using smartphone apps, necessary for his work. He caused a car crash when trying to use his smartphone while driv- ing and, a few days later, damaged two tyres while parking. After this, his family persuaded him to stop working, which made him feel increasingly sad and "useless".

Two years later, he started complaining of "ants" crawling on his head. He started scratching and picking it, claiming that an "ants nest" had infested his scalp. This belief firmly persisted despite being contradicted by his family and given the logical arguments against it. He was restless at night, with excessive limb movements and talking while asleep. He started seeing small nonexistent animals, like spiders, frequently. In addition, he was also hearing sounds inaudible to others such as whistling and buzzing sounds, which he sometimes attributed to the "bugs", besides hearing his name being called or the doorbell ringing several times a day. Since giving up work, he had persistent depressive symptoms, which included loss of interest in previously pleasurable activities and interactions with his family, persistent low mood and sobbing, self-deprecating ideas such as recurring thoughts of feeling useless and a burden to his family, low energy, apathy and hyporexia.

He remained independent for basic activities of daily living, but was already dependent for instrumental activities, such as cooking and financial management. Upon arrival at our service, he already displayed initial memory deficits, repeating himself in conversations and forgetting recent events.

At neurological examination, he was lucid with hypomimia and hypophonia, presenting unsteady gait with reduced arm movements, mild postural instability on the pull test, moderate bilateral bradykinesia in upper and lower limbs, mild cogwheel rigidity, no resting or kinetic tremor, with preserved muscle strength and no disturbances in sensitivity. MDS-UPDRS ${ }^{21}$ total score was 64 . Psychiatric evaluation detected apathy and passivity, overall low mood, few expressions of emotion, mostly when talking about the "ants" on his head, indicating where he felt them, and expressing great anguish. He also cried while talking about his past performance at work and home compared to his current status, demonstrating insight of his deficits. He had no trouble remembering remote past life events and memory problems were restricted to recent events.

On the initial cognitive assessment, he scored 25/30 points on the MMSE; ${ }^{22,23} 9$ points on the semantic verbal fluency test $\mathrm{t}^{24}$ (animals category) and $2 / 3$ points on the clock-drawing test. ${ }^{26}$ He scored $16 / 30$ points on the $\mathrm{MoCA}^{26,27}$ and was classified as CDR 1 on the Clinical Dementia Rating scale. ${ }^{28,29}$ Extensive neuropsychological testing was performed, revealing immediate and delayed verbal memory recall deficits, moderate to severe execu- 


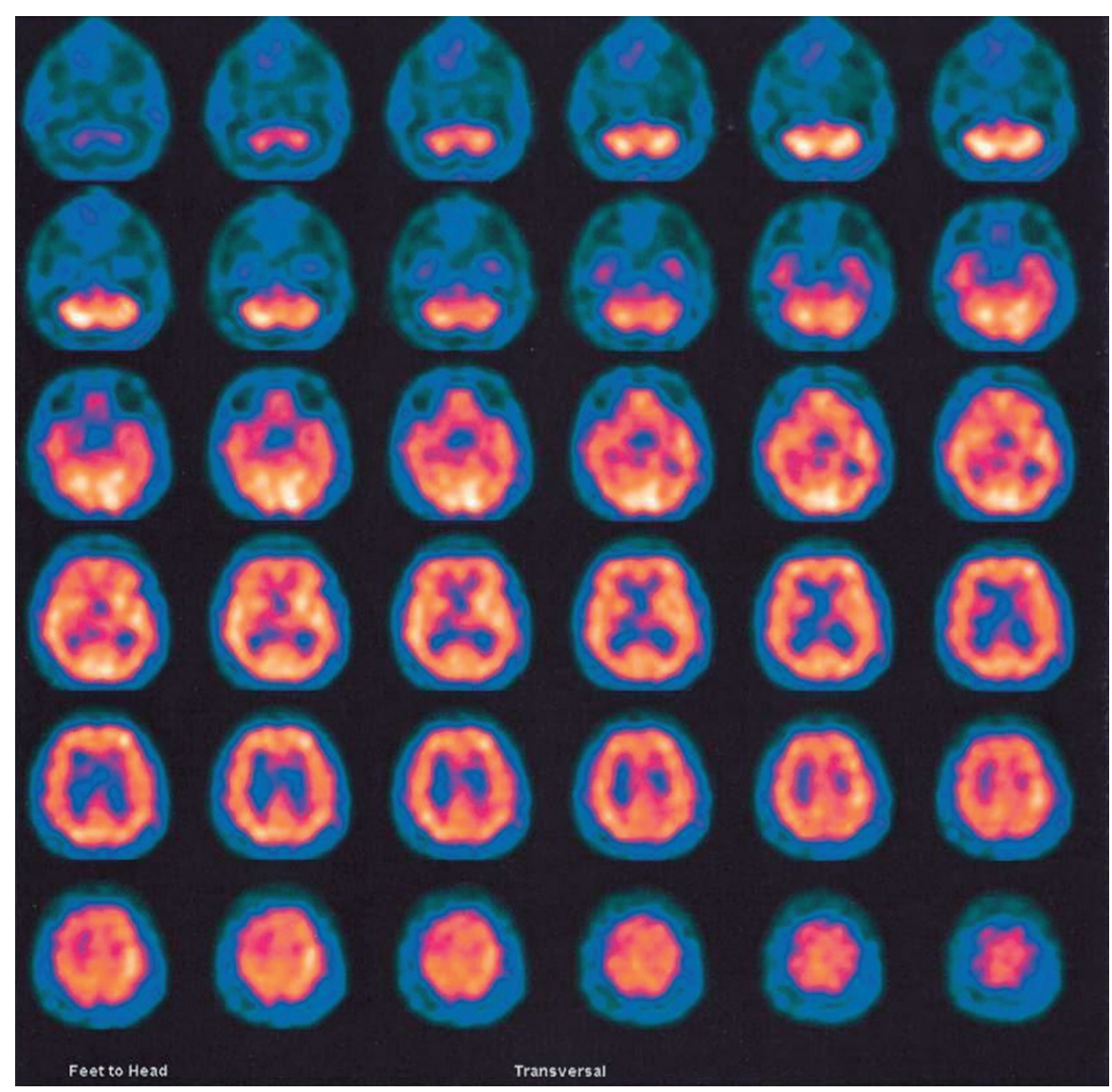

Figure 1. DAT SPECT imaging showing reduced radiotracer uptake in the basal ganglia.

tive dysfunction, including difficulties with sequencing, planning, cognitive flexibility, and deficits in abstracting and conceptualizing abilities. He scored 37 points on the Neuropsychiatric Inventory (NPI), ${ }^{30,31}$ mainly involving the categories: hallucinations, depression, apathy/indifference, sleep and appetite disturbances.

Brain MRI revealed diffuse cortical atrophy and mild microangiopathy predominantlin frontoparietal and periventricular subcortical white matter, and mild bilateral hippocampal reduction, all compatible with the patient's age and degree of cortical atrophy. Perfusion SPECT study showed no abnormalities; the DAT SPECT imaging, however, revealed reduced radiotracer uptake in the basal ganglia indicating moderate nigro-striatal dysfunction (Figure 1). MIBG-123I Cardiac Scintigraphy was also performed, suggesting significant cardiac sympathetic denervation (Figure 2). Polysomnography was inconclusive, as the patient did not achieve REM sleep. The diagnosis of probable LBD was established based on clinical symptoms and presence of two positive biomarkers.

Depressive symptoms were initially treated with citalopram. Rivastigmine was then started and titrated to maximum daily dose. Most of the hallucinatory and delusional symptoms improved significantly only after starting on AChEI, and Ekbom syndrome disappeared, with no need for antipsychotic medication.

\section{DISCUSSION}

A diagnosis of probable Lewy Body Dementia was established considering the criteria of the latest consensus of experts. Two of the four core clinical features were present: visual hallucinations and spontaneous parkinsonism. There were also symptoms suggestive of REM sleep behavior disorder. It is noteworthy that initial cognitive symptoms were not memory deficits, but attention, executive and visuospatial deficits, as expected in LBD. Supporting clinical features were also present: postural instability; hallucinations in other modalities (auditory, tactile); delusions of insect infestations; depression. LBD is known for its tendency to cause sensory and perceptual disturbances early in the disease course. Tactile hallucinations were part of the Ekbom syndrome presented by the patient, leading to self-harm. Two of the indicative biomarkers were positive: the DAT SPECT imaging and MIBG Myocardial 


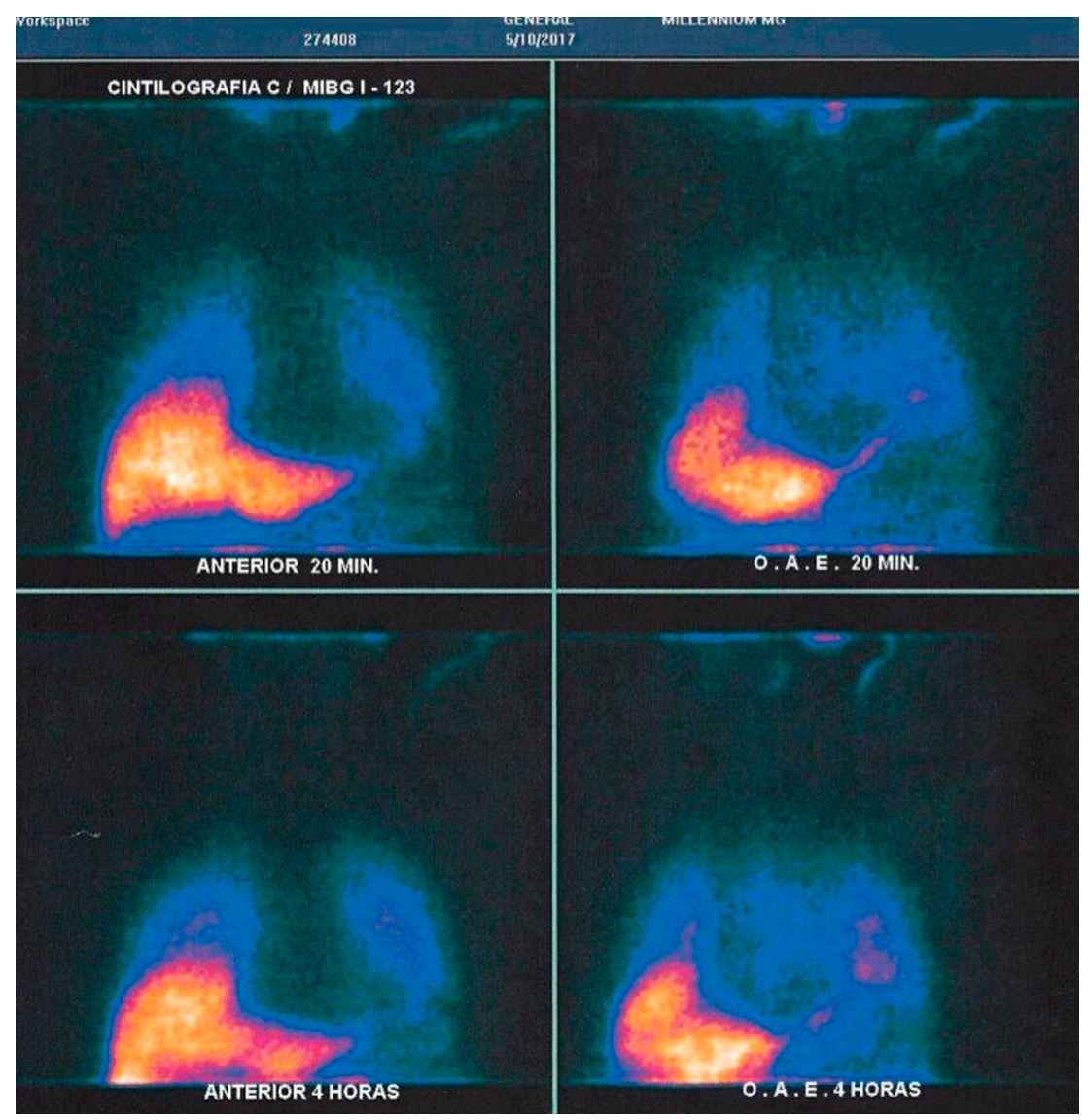

Figure 2. MIBG-123I Scintigraphy showing reduced radiotracer uptake in cardiac chambers, indicating significant sympathetic denervation.

scintigraphy. A supporting biomarker - the structural MRI showing preservation of medial temporal structures - was helpful to exclude Alzheimer's disease. Moreover, motor symptoms only surfaced two years after the onset of cognitive symptoms, excluding the diagnosis of Parkinson's disease.

Management of psychotic symptoms in LBD is challenging, given the uncertain benefits of antipsychotic use, together with the risks of serious adverse events. A few studies, with less rigorous methodology in LBD and Parkinson's Disease Dementia, have failed to demonstrate evidence of efficacy of antipsychotics in these conditions. Expert consensus suggests that clozapine and quetiapine may be considered as options to control distressing behavioral symptoms in LBD, but careful monitoring for clozapine, lack of evidence for quetiapine, severe neuroleptic sensitivity and overall increased mortality constitute additional concerns inherent to these choices. ${ }^{32}$ In this scenario, AChEIs represent plausible options. In a recent systematic review of pharma- cological strategies in LBD, AChEIs demonstrated good evidence for controlling cognitive and behavioral symptoms, suggesting that these medications can be a reasonable first choice to treat psychotic symptoms. ${ }^{32}$

As illustrated here, there is a need for increasing awareness of late onset psychiatric symptoms as a dementia prodrome. Proper diagnosis can guide disease management and provide maximum benefit, while minimizing adverse effects, the mainstay of good medical practice.

Grant support acknowledgement. This study was conducted in the absence of grant support.

Author contributions. Felippe José Pontes de Mendonça: was involved in designing the study, collecting the data, and writing the paper. Ivan Abdalla Teixeira: assisted with the writing. Valeska Marinho: involved in designing the study, supervising the data collection, and assisting with the writing. 


\section{REFERENCES}

1. Ekbom KA. Der praesenile dermatozoenwahn. Acta Psychiatr Neurol 1938;13:227-59.

2. Munro A. Monosymptomatic hypochondriacal psychosis. Br J Psychiatry. 1988;153:37-40.

3. Slaughter JR, Zanol K, Rezvani H, Flax J. Psychogenic parasitosis: a case series and literature review. Psychosomatics. 1998;39:491-500.

4. Nagaratnam N, O'Neil L. Delusional parasitosis following occipitotemporal cerebral infarction. Gen Hosp Psychiatry. 2000; 22:129-132

5. Cummings JL. Organic delusions: phenomenology, anatomical correlations and review. Br J Psychiatry. 1985;14:184-97.

6. Bhatia MS, Gautam P, Kaur J. Ekbom syndrome occurring with multiinfarct dementia. J Clin Diagn Res. 2015;9(4):VD03-VD04.

7. Trabert W. 100 years of delusional parasitosis: meta-analysis of 1203 case reports. Psychopathology. 1995;28(5):238-46.

8. Amâncio EJ, Peluso CM, Santos ACG, Magalhães CCP, Pires MFC, Dias APP, et al. Síndrome de Ekbom e torcicolo espasmódico. Arq Neuropsiquitr. 2002;60(1):155-8.

9. Meira-Alves CJ, Martelli ACC, Fogagnolo L, Nassif PW. Síndrome de Ekbom secundária a transtorno orgânico - relato de três casos. An Bras Dermatol. 2010;85(4):541-4.

10. Goi PD, Scharlau CT. Síndrome de Ekbom acompanhada de automutilação. Rev Psiquiatr Rio Gd Sul vol 29 n¹ Porto Alegre - Jan/Abr. 2007.

11. Jones SV, O'Brien JT. The prevalence and incidence of dementia with Lewy bodies: a systematic review of population and clinical studies. Psychol Med. 2014;44(4):673-83.

12. Brucki SMD, Rodriguez RD. Demência com corpos de Lewy. In: Forlenza OV, Radanovic M, Aprahamian I, editors. Neuropsiquiatria Geriátrica, $2^{a}$ edição; São Paulo, Atheneu, 2017. p 273-8.

13. McKeith IG, Boeve BF, Dickson DW, Hallyday G, Taylor JP, Weintraub D, et al. Diagnosis and management of dementia with Lewy bodies - fourth consensus report of the DLB consortium. Neurology 2017;89:88-100.

14. Takahashi S, Mizukami K, Yasuno F, Asada T. Depression associated with dementia with Lewy Bodies (DLB) and the effect of somatotherapy. Psychogeriatrics. 2009;9(2):56-61.

15. Perera JK, Rosenblat JD, Flint AJ. Dementia with Lewy Bodies presenting as Psychotic Depression. Aust N Z J Psychiatry. 2017;51(11):1160-1.

16. Lakshmana R, Sundram S, Cairns F. Dementia with Lewy Bodies (DLB) presenting with catatonic symptoms. Psychogeriatrics. 2006:6:31-34.

17. Thaipisutikul P, Lobach I, Zweig Y, Gurnani A, Galvin JE. Capgras Syndrome in Dementia with Lewy Bodies. Int Psychogeriatr. 2013;25(5): 843-9.

18. Magierski R, Magierska J, Kloszewska I, Sobow T. Dementia with lewy bodies manifested as delusional parasitosis (Ekbom's syndrome). Alzheimers Dementia 2015;11(Suppl.):781-2.
19. McKeith I, Fairbairn A, Perry R, Thompson P, Perry E. Neuroleptic sensitivity in patients with senile dementia of Lewy body type. BMJ 1992;305(6855):673-8.

20. Boot BP. Comprehensive treatment of dementia with Lewy bodies Alzheimers Res Ther. 2015:7(1):45.

21. Goetz CG, Tilley BC, Shaftman SR, Stebbins GT, Fahn S, MartinezMartin P, et al. Movement Disorder Society-Sponsored Revision of the Unified Parkinson's Disease Rating Scale (MDS-UPDRS): Scale Presentation and Clinimetric Testing Results. Mov Disord. 2008;23(15):2129-70.

22. Folstein MF, Folstein SE, McHugh PR. "Mini-mental state". A practical method for grading the cognitive state of patients for the clinician. $J$ Psychiatry Res. 1975;12(3):189-98.

23. Bertolucci PHF, Brucki SMD, Campacci SR, Juliano Y. O Mini-Exame do Estado Mental em uma população geral: impacto da escolaridade. Arq Neuropsiquiatr. 1994;52(1):1-7.

24. Brucki SMD, Malheiros SMF, Okamoto IH, Bertolucci PHF. Dados normativos para o teste de fluência verbal categoria animais em nosso meio. Arq Neuropsiquiatr. 1997;55(1):56-61.

25. Fuzikawa C, Lima-Costa MF, Uchoa E, Barreto SM, Shulman K. A population based study on the intra and inter-rater reliability of the clock drawing test in Brazil: the Bambuí health and ageing study. Int J Geriatr Psychiatry. 2003;1895:450-6.

26. Nasreddine ZS, Phillips NA, Bédirian V, Charbonneau S, Whitehead V, Collin I, et al. The Montreal Cognitive Assessment, MoCA: a brief screening tool for mild cognitive impairment. J Am Geriatr Soc. 2005; 53(4):695-9.

27. Sarmento ALR, Bertolucci PHF, Waiman JR. MoCA: versão experimental brasileira. São Paulo: UNIFESP; 2007. Disponível em: https://www. mocatest.org/wp-content/uploads/2015/test-instructions/\%20MoCATest-Portuguese_Brazil.pdf

28. Hughes CP, Berg L, Danziger WL, Coben LA, Martin RL. A new clinical scale for the staging of dementia. Br J Psychiatry. 1982;140:566-72.

29. Macedo Montaño MBM, Ramos LR. Validade da versão em português da Clinical Dementia Rating. Rev Saúde Pública 2005;39(6):912-17.

30. Cummings JL, Mega M, Gray K, Rosenberg-Thompson S, Carusi DA Gornbein J. The Neuropsychiatric Inventory: comprehensive assessment of psychopathology in dementia. Neurology. 1994;44:2308-14

31. Camozzato AL, Kochhann R, Simeoni C, Konrath CA, Pedro Franz A, Carvalho A, et al. Reliability of the brazilian portuguese version of the Neuropsychiatric Inventory (NPI) for patients with Alzheimer's disease and their caregivers. Int Psychogeriatr 2008;20(2):383-93.

32. Stinton C, McKeith I, Taylor JP, Lafortune L, Mioshi E, Mak E, et al. Pharmacological management of Lewy body dementia: a systematic review and meta冈analysis. Am J Psychiatry 2015;172:731-2. 